University of Nebraska - Lincoln

DigitalCommons@University of Nebraska - Lincoln

Beef Species Symposium: Potential limitations of NRC in predicting energetic requirements of beef females within western U.S. grazing systems

\author{
M. K. Petersen \\ USDA-ARS, mark.petersen@ars.usda.gov \\ C. J. Mueller \\ Oregon State University \\ J. T. Mulliniks \\ University of Tennessee, travis.mulliniks@unl.edu
}

A. J. Roberts

USDA-ARS, andy.roberts@ars.usda.gov

T. DelCurto

Oregon State University

See next page for additional authors

Follow this and additional works at: https://digitalcommons.unl.edu/usdaarsfacpub

Petersen, M. K.; Mueller, C. J.; Mulliniks, J. T.; Roberts, A. J.; DelCurto, T.; and Waterman, R. C., "Beef Species Symposium: Potential limitations of NRC in predicting energetic requirements of beef females within western U.S. grazing systems" (2014). Publications from USDA-ARS / UNL Faculty. 1441. https://digitalcommons.unl.edu/usdaarsfacpub/1441

This Article is brought to you for free and open access by the U.S. Department of Agriculture: Agricultural Research Service, Lincoln, Nebraska at DigitalCommons@University of Nebraska - Lincoln. It has been accepted for inclusion in Publications from USDA-ARS / UNL Faculty by an authorized administrator of DigitalCommons@University of Nebraska - Lincoln. 


\section{Authors}

M. K. Petersen, C. J. Mueller, J. T. Mulliniks, A. J. Roberts, T. DelCurto, and R. C. Waterman 


\title{
BEEF SPECIES SYMPOSIUM: Potential limitations of NRC in predicting energet- ic requirements of beef females within western U.S. grazing systems ${ }^{1,2}$
}

\author{
M. K. Petersen, ${ }^{* 3}$ C. J. Mueller, $\dagger$ J. T. Mulliniks, + A. J. Roberts, $*$ T. DelCurto, $\dagger$ and R. C. Waterman* \\ *USDA-ARS, Fort Keogh Livestock and Range Research Laboratory, Miles City, MT 59301; \\ $\dagger$ Eastern Oregon Agricultural Research Center, Oregon State University, Union 97883; \\ and $\$$ Department of Animal Science, University of Tennessee, Crossville, TN, 38571
}

\begin{abstract}
Assessment of beef cow energy balance and efficiency in grazing-extensive rangelands has occurred on a nominal basis over short time intervals and has not accounted for the complexity of metabolic and digestive responses; behavioral adaptations to climatic, terrain, and vegetation variables; and documentation of the effects of nutrient form and supply to grazing cattle. Previous research using pen-fed cows demonstrated differences $(P<0.01)$ in efficiency of weight change ranging from 135 to $58 \mathrm{~g} / \mathrm{Mcal} \mathrm{ME}$ intake. Furthermore, variation in efficiency of ME use for tissue energy gain or loss ranged from $36 \%$ to $80 \%$. In general, energy costs for maintenance, tissue accretion, and mobilization were greatest in Angus-based cows, intermediate in Brahmanand Hereford-based cows, and least in dairy-based cows. The most efficient cattle may reflect the types that are successful in semiarid grazing environments with low input management. Successful range cattle systems are likely the result of retention of animals that best adapted to the grazing environment and thus were potentially more efficient. Animals exposed to a variety of stressors may continually
\end{abstract}

adapt, so energy expenditure is reduced and may tend to depart from the modeled beef cow in the 1996 NRC Beef Cattle Requirements. Critical factors comprising cow lifetime achievement, including reproductive success, disease resistance, and calf weaning weight, may be driven by cow total energy utilization in energy-limiting environments. Therefore, energy adjustments for adapted cattle within these landscapes and seasonal BW changes can alter seasonal $\mathrm{NE}_{\mathrm{m}}$ requirements. Evaluated studies indicate that in static grazing environments, NRC prediction fitness was improved compared with predictions from dynamic systems where cattle were influenced less by management and more by environmental conditions. Preliminary herd analyses cast doubt on the accuracy of NRC BCS descriptions representing $\mathrm{NE}_{\mathrm{m}}$ requirements of adapted females utilizing semiarid rangelands. Possible gaps are proposed that could be the basis for prediction inaccuracies. A more complete understanding of mechanisms contributing to productivity in the field than the current model predicts will improve future models to better simulate energetic accountability and subsequent female performance.

Key words: beef cattle, condition scores, energy requirements, NRC

(C) 2014 American Society of Animal Science. All rights reserved.

J. Anim. Sci. 2014.92:2800-2808

doi:10.2527/jas2013-7310

\section{INTRODUCTION}

\footnotetext{
${ }^{1}$ Based on a presentation at the Beef Species Symposium titled "Nutrient requirements of the beef female in extensive grazing systems: Considerations for revising the beef NRC" at the Joint Annual Meeting, July 8-12, 2013, Indianapolis, IN.

${ }^{2}$ USDA, Research Service, Northern Plains Area, is an equal opportunity/affirmative action employer. All agency services are available without discrimination. This research was conducted under a cooperative agreement between USDA-ARS and the Montana Agricultural Experiment Station. Mention of a proprietary product does not constitute a guarantee or warranty of the product by USDA, Montana Agricultural Experiment Station, or the authors and does not imply its approval to the exclusion of other products that also may be suitable.

${ }^{3}$ Corresponding author: mark.petersen@ars.usda.gov

Received October 25, 2013.

Accepted January 7, 2014.
}

Grazing beef cattle adapt, cope with, or benefit from environmental- or managerial-imposed conditions. The scale of inconsistency between differing grazing environments is thought to be as great as, if not greater than, known diversity in vegetation density, nutrient composition of vegetation, climate, terrain type, nutritional management, intensity and duration of cattle activity, and the effects of year. There appear to be trends in certain grazing environments that predicted productivity of brood cows using the 1996 NRC nutrient requirements of beef cattle (1996NRC; NRC, 
2000) is not as accurate as outcomes produced for confinement fed cattle. These trends indicate that the provision of subroutines in the 1996NRC models may account for additional factors to allow for better prediction accuracy. Arid and semiarid environments can generally be characterized by sparse forage density, long traveling distances to satisfy intake requirements, exposure to climatic elements and inconsistencies, and minimal implementation of management practices for behavioral and energetic adaptions. Constant exposure to these factors may cause stress on cattle, prompting metabolic adaptation that results in performance outcomes different from cattle produced in more nutrient-rich environments. The objective of this paper is to assess research herd production data in comparison with the 1996NRC performance predications and provide suggestions to potentially address information gaps that may lead to the development of better prediction models for range cattle productivity.

\section{BACKGROUND AND PREVIOUS ASSESSMENTS OF THE 1996 BEEF NRC}

The publication of the 1996 NRC nutrient requirements of beef cattle (NRC, 2000) was a further progression of the advancements of animal sciences in regard to interactions of nutrition, the environment, and physiology. The 1996NRC models attempted to incorporate more physiological and microbial interactions in regard to energy, protein, and DM intake systems. As the 1996NRC gained usage by both researchers and industry representatives, it became apparent that the prediction models were more satisfactory for growing and finishing cattle but highly irregular and poorly correlated to grazing cattle (DelCurto et al., 2000). Grazing cattle, especially mature cows, in western U.S. grazing conditions seemed to respond differently in regard to ME efficiencies and partitioning uses compared with the 1996NRC prediction models. From an energetic standpoint both the 1984 (1984NRC; NRC, 1984) and 1996NRC beef cattle requirements indicate that cow $\mathrm{BW}$, potential milk yield, and changes in BCS are reliable indicators of relative TDN requirements of gestating beef cows.

Energy Model Advancements from 1984NRC to 1996NRC. The 1984NRC requirements for beef cows revolved primarily around BW, calf BW at birth, quality and quantity of lactation, and whether or not the cow was "thin" or "normal." The 1996NRC equations included adjustment variables presented in the 1984NRC but also adjustment factors for breed, previous plane of nutrition, and activity. Although the 1996NRC does not independently adjust for calf BW at birth and lactation attributes, it does incorporate breed adjustments that attempt to account for differences in both calf BW at birth and 24-h milk yield across the major beef breeds. Previous plane of nutrition is based on estimated body composition of the cow at BCS 5.0 (1 to 9 scale), adjusted based on whether BCS is declining or improving. The 1996NRC suggests $\mathrm{NE}_{\mathrm{m}}$ requirements increase by $25 \%$ when BCS is declining compared with increasing by $1.0 \mathrm{BCS}$, as a result of potentially altered kinetics of fat and protein metabolism between positive and negative energy balance. The 1984NRC attempted to adjust for differences in body condition by comparing with a common BW to height at the hooks ratio (4.0:1) and then multiplying by $1.716 \mathrm{Mcal} \mathrm{NE}_{\mathrm{m}}$ (Klosterman et al., 1968). Although the use of BCS to adjust for plane of nutrition is more subjective and erroneous vs. BW and hip height measures, it attempts to account for changes in body composition and subsequent energetic dynamics and is more convenient and cost-effective.

The other major change from the 1984NRC requirements was a $\mathrm{NE}_{\mathrm{m}}$ adjustment for grazing activity (ACTIVITY). The ACTIVITY adjustment attempts to account for energy expenditures of grazing cattle (both breeding and growing cattle). The 1996NRC adjustment is $(\{0.006 \times \mathrm{pI} \times[0.9 \times(\mathrm{TDNp} / 100)]\}+\{0.05 \times$ TERRAIN $/[(0.002471 \times$ pAVAIL $)+3]\}) \times \mathrm{BW} / 4.184$; where $\mathrm{pI}$ is DM intake of pasture, TDNp is estimated TDN of pasture, TERRAIN is either "level" or "hilly," and pAVAIL is mass of pasture ( $t / h a)$. The authors of the 1996NRC acknowledged that grazing animals had greater energy expenditures vs drylot cattle, but little data were available to accurately estimate the energy adjustments for associated grazing activities and whether or not these expenditures were a function of maintenance or production (NRC, 2000).

Uniqueness of the Western U.S. Production Environment. Production of forages is dependent on a variety of factors. In the western U.S., soil type (fertility and water-holding capacity), precipitation totals and patterns, and topography have profound impacts that may not be as prominent in other parts of the United States. Rangeland systems in the western United States are typically classified as arid to semiarid, with annual precipitation amounts ranging from $216 \mathrm{~cm}$ in the coastal ranges of Washington, Oregon, and northern California to $12 \mathrm{~cm}$ in the Great Basin region of Oregon, Nevada, and Utah (National Climatic Data Center, 2013). Most rangelands west of the 103rd meridian receive between 25 and $38 \mathrm{~cm}$ of precipitation annually (National Climatic Data Center, 2013). Topography of the western United States has an impact on forage production and grazing management as well. Grazing mainly occurs in regions at or slightly below sea level ( $\leq 0 \mathrm{~m}$ of elevation; coastal ranges) to 2,600 $\mathrm{m}$ of elevation. Changes in elevation can impact precipitation patterns and locations, along with type of forages (DelCurto et al., 2013) and grazing behavior (DelCurto et al., 2005). Cattle in different environments, because of extensiveness of pasture size, can exhibit differences 
in energy expenditure and ultimately energy utilization. Cows in extensive environments can travel in excess of $13 \mathrm{~km} / \mathrm{d}$ (Russell et al., 2012), whereas cows managed in small paddocks may only travel up to $3 \mathrm{~km} / \mathrm{d}$ (Davis et al., 2011). Also unique to the western United States is the reliance on federal grazing permits by both U.S. Bureau of Land Management and USDA Forest Service, which influence grazing seasons, duration, and management practices. The combination of soil type, precipitation, topography, and allowable grazing periods impact the type, productivity, and nutritive value of forages produced for grazing beef cattle. These variables alone can influence energy intake and expenditures of grazing beef cattle in the western United States.

Energy Models Are Dependent on Accurate TDN Estimates. The supply of energy to the animal is based on estimating apparent TDN of the feedstuff and then converting to $\mathrm{ME}, \mathrm{NE}_{\mathrm{m}}, \mathrm{NEg}$, and $\mathrm{NE}_{1}$ values (NRC, 2000). The estimation of apparent TDN in the 1996NRC is based on estimates of apparent digestibility and microbial yield, both of which are based on chemical composition of the feedstuff. Although DM intake and protein metabolism are discussed in subsequent proceedings, both variables are intimately linked to supply of energy to the beef animal.

Chemical composition of forages can be determined from random sites within grazing areas that were manually clipped or collected through the use of rumen-cannulated cattle and chemically analyzed. Using random clippings of grazing areas provides adequate estimates of overall grazing nutrition of monoculture plant communities but can be highly erroneous in areas of diverse plant communities and grazing periods. Darambazar et al. (2007) and Wyffels et al. (2013) reported that beef cows grazing Pacific Northwest native bunchgrass communities in late spring, early summer selected primarily introduced vegetative communities that represented $\leq 25 \%$ of the available herbage. Wyffels et al. (2013) also reported that grazing later in the spring-summer season, along with greater stocking rates, resulted in greater utilization of native vegetative communities. The bite count method (Bjugstad et al., 1970; Damiran et al., 2013) used by DelCurto et al. (2013) and Wyffels et al. (2013) illustrated the selectivity of beef cows in western range conditions, but it also underscores the difficulty in determining quantity and quality of grazed forages. Therefore, the accuracy in estimating nutritional quality (and quantity) in western rangelands is difficult and therefore lends itself to major inaccuracies in estimating TDN and predicting outcomes such as body composition and lactation yield by grazing beef cows.

Previous Evaluations of 1996NRC Energy Models. An overview of past research evaluating beef cows using the 1996NRC energy models has indicated that many of the new variables introduced in 1996NRC models are inconsistent and problematic compared with actual animal performance. Lardy et al. (2004) attempted to verify aspects of the MP and TDN models against both springand summer-calving cows grazing warm- and cool-season grasses in the Nebraska Sandhills region. Although much of their discussion revolved around the MP model and microbial yield, they also eluded to the fact that energy models did not predict cow performance and change in BCS during both years of the study. In addition, these authors reported that 1996NRC-predicted spring-calving cows consuming meadow hay would have small energy deficiencies, which was also observed in spring-calving cows consuming similar meadow hay (HollingsworthJenkins et al., 1996). Although 1996NRC energy predictions and observations between Lardy et al. (2004) and Hollingsworth-Jenkins et al. (1996) were similar, the close alignment of prediction and observations occurred during the winter months when calves would have been weaned (i.e., with no $\mathrm{NEl}$ requirement) and cows would have been in middle to late gestation (i.e., with minimal energetic expenditures from the gravid uterus). Lardy et al. (2004) also reported 1996NRC models predicted summer-calving cows grazing either subirrigated meadows or native range would experience energy deficiencies, especially during the fall-winter months. In fact, Lardy et al. (2004) reported that 1996NRC energy deficiency predictions during the fall and winter months were biologically unreasonable $(-7.9$ to $-8.4 \mathrm{Mcal} / \mathrm{d}$ for native range and subirrigated meadows, respectively), and a lack of adequate diet data may have contributed to the errant predictions. Lardy et al. (2004) also indicated that the ACTIVITY model in 1996NRC should not be used. As an example, Lardy et al. (2004) reported use of the "on pasture" feature increased the energy deficiency by $540 \%$, and the subsequent use of "hilly" to describe the grazing terrain resulted in a $670 \%$ negative $\mathrm{NE}_{\mathrm{m}}$ balance. Lardy et al. (2004) indicated that additional research and data compilation are needed in regard to microbial efficiency (which impacts both energy and MP predictions), diet chemistry of multiple cool- and warm-season grasses and forbs (within and across seasons), and effects of environment and topography on cow performance.

Patterson et al. (2006) evaluated the application of the 1996NRC protein and energy models using cow data from 8 previously published data sets representing Nebraska and Montana. When comparing 1996NRC BCS predictions with actual BCS changes, they determined the 1996NRC performed satisfactorily as long as 1) predicted TDN based on in vitro OM disappearance (IVOMD) was converted to DE (Rittenhouse et al., 1971), 2) model adjustments for ACTIVITY were not used, and 3) model adjustments for environmental conditions were adjusted to indicate that cattle were acclimated to the temperature. Patterson et al. (2006) also acknowledged forage intake 
was predicted using the NRC model (NRC, 2000), and short modeling periods $(\leq 30 \mathrm{~d})$ work the best for late gestating and early lactating cows and during periods of rapid nutrient quality change. This would indicate the ability to quantify DM or forage intake is critical in developing energy models, and periods of active physiological change (either animal or plant) are more dynamic than current model structures can predict. Patterson et al. (2006) also indicated additional research to more precisely define microbial efficiency, especially on low-quality forage diets, is critical to both the energy and protein models used in the 1996NRC.

Block et al. (2010) evaluated the 1996NRC energy and DMI models using middle and late gestation Angus beef cows wintered in western Canada. Cows were managed in a drylot situation and received a total mixed ration. For both DMI and ADG, 1996NRC inaccurately predicted the observed responses with poor precision. The authors further compared responses using actual environmental variables vs. thermal neutral values. Block et al. (2010) reported the use of thermal neutral values seemed to slightly improve prediction accuracies for both DMI and ADG within gestation periods but did not account for large portions of the prediction error. Therefore, Block et al. (2010) concluded that the 1996NRC prediction equations for both DMI and energy were flawed and presented unacceptable predictions of actual outcomes to be valuable to beef producers. The study by Block et al. (2010) attempted to evaluate beef cows in a drylot setting with mixed diets at a set period of time each day. Unfortunately, this type of feed setting does not allow for evaluation of the ACTIVITY model (NRC, 2000), and some authors have suggested altered intake activity and physiological responses of cattle in a drylot vs. grazing setting (Albright, 1993; Ray and Roubicek, 1971). Additionally, the study by Block et al. (2010) used cows that were approximately 39 mo of age the first winter, 51 mo of age the second winter, and 63 mo of age the third winter, which potentially could have confounded growth with both DMI and energy predictions. Block et al. (2010) indicated additional research is needed in regard to changes in cow body and tissue composition, environmental influences on acclimation, and refinement of $\mathrm{NE}_{\mathrm{m}}$ requirements specifically for mature beef cows.

\section{CASE STUDIES: INTENSIVE AND EXTENSIVE COW GRAZING SCENARIOS}

Cattle in the United States graze various unique environments, which differ in climate, topography, and forage quality and quantity. These differences are accentuated by dynamic and unpredictable weather patterns and thus impact forage production and subsequently increase variability in cow performance. Therefore, comparing case studies from Virginia, Tennessee, eastern
Table 1. Actual and NRC-predicted cow BW and BW change from mature cows in Virginia ${ }^{1}$

\begin{tabular}{lrrrc}
\hline \hline Item & Actual & 1996NRC $^{2}$ & SEM & $P$-value \\
\hline Trial 1 & & & & \\
$\quad$ BW, kg & 693 & 699 & 9 & - \\
$\quad$ BW change, kg/d & 4 & 9 & 5 & 0.51 \\
Trial 2 & & & & \\
$\quad$ BW, kg & 572 & 553 & 9 & - \\
BW change, kg/d & 5 & 6 & 5 & 1.00 \\
\hline
\end{tabular}

${ }^{1}$ Adapted from Horsley (2002).

${ }^{2}$ Predictions based on Model 1 outputs published for beef cattle (NRC, 2000).

Oregon, central New Mexico, and eastern Montana will help determine the efficacy of the 1996NRC predictions across dynamic environments, management strategies, and cow types. For each environmental scenario, actual cow performance was averaged and analyzed across year and compared with the 1996NRC-predicted outcomes. Predicted ADG from the 1996NRC was calculated using $36 \mathrm{~kg}$ to change a BCS. Evaluations were based on Model 1 of the $1996 \mathrm{NRC}$, with microbial yield set at $8 \%$ and all other inputs left as "default."

Virginia. To evaluate the accuracy of the 1996NRC with actual cow performance in Virginia, Horsley (2002) conducted 2 research trials utilizing mature beef cows ( $n=70$ and 64 in trials 1 and 2; respectively). In both trials, cows were weighed, and forage samples were manually clipped for nutrient analysis every $28 \mathrm{~d}$. In comparison with actual mean BW, 1996NRC overpredicted mean BW by $0.92 \%$ and $3.25 \%$ in trials 1 and 2 , respectively (Table 1). Thus, a strong correlation was reported between actual and 1996NRC-predicted BW $(P<0.01$; $r=0.82$ and 0.64 for trials 1 and 2 , respectively). In addition, actual and 1996NRC-predicted mean BW change were similar $(P=0.51$ and 1.00 for trials 1 and 2, respectively). Predictions from the 1996NRC closely followed gain trends and accurately estimated the change in actual cow performance. When evaluating an annual production cycle, Horsley (2002) suggested that 1996NRC estimates of cow ADG, BW, and BCS change typically were not different from actual performance and can accurately predict actual animal performance.

Tennessee. Eight years of performance data of heifers, 3-yr-old cows, and 6-yr-old cows from the University of Tennessee (J. T. Mulliniks, unpublished data) were used to compare actual and 1996NRC-predicted performance (Table 2). The feeding managements of the heifers were 1) $6.8 \mathrm{~kg} / \mathrm{d}$ of corn silage and ad libitum access to orchard grass hay $(9 \% \mathrm{CP}$ and $63 \% \mathrm{NDF})$ from September to December, 2) $13.6 \mathrm{~kg} / \mathrm{d}$ corn silage and ad libitum access to orchard grass hay for January and February, 3) ad libitum corn silage, cracked corn, and cottonseed meal ration for March and April, and 4) grazed fescue pastures from May to September. Three- and 6-yr-old cows were fed 1) 
Table 2. Actual and NRC-predicted ADG for heifers, 3-yr-old cows, and 6-yr-old cows from the East Tennessee Research and Education Center in Knoxville, $\mathrm{TN}^{1}$

\begin{tabular}{|c|c|c|c|c|}
\hline Item & Actual & $1996 \mathrm{NRC}^{2}$ & SEM & $P$-value \\
\hline \multicolumn{5}{|c|}{ Wean to pre-calving ADG, $\mathrm{kg} / \mathrm{d}$} \\
\hline Heifers & 0.68 & 0.64 & 0.05 & 0.78 \\
\hline 3-yr-old cows & 0.73 & 0.59 & 0.09 & 0.62 \\
\hline 6-yr-old cows & 0.64 & 0.55 & 0.07 & 0.89 \\
\hline \multicolumn{5}{|c|}{ Precalving to prebreeding ADG, $\mathrm{kg} / \mathrm{d}$} \\
\hline Heifers & 1.00 & 1.23 & 0.23 & 0.66 \\
\hline 3-yr-old cows & -0.14 & 0.15 & 0.14 & 0.08 \\
\hline 6-yr-old cows & -0.42 & 0.14 & 0.18 & 0.03 \\
\hline \multicolumn{5}{|c|}{ Prebreeding to weaning ADG, $\mathrm{kg} / \mathrm{d}$} \\
\hline Heifers & 0.73 & 0.82 & 0.09 & 0.53 \\
\hline 3-yr-old cows & -0.05 & 0.32 & 0.18 & 0.21 \\
\hline 6-yr-old cows & -0.05 & 0.23 & 0.18 & 0.32 \\
\hline
\end{tabular}

${ }^{1}$ Source: J. T. Mulliniks, unpublished data.

${ }^{2}$ Predictions based on Model 1 outputs published for beef cattle (NRC, 2000).

ad libitum orchard grass hay from December to February, 2) $13.6 \mathrm{~kg} / \mathrm{d}$ of corn silage and ad libitum access to orchard grass hay from calving (February) until breeding (April), and 3 ) grazed fescue pastures from the end of breeding (April) until December. Cows were managed in an intensive management system and maintained a high $\operatorname{BCS}(\geq 6)$ with heavy weaned calves $(\sim 318 \mathrm{~kg} / \mathrm{cow})$. From weaning to precalving, $1996 \mathrm{NRC}$ models accurately predicted $(P \geq$ 0.62; Table 2) cow ADG for every class of female. Heifer ADG from precalving to prebreeding was accurately predicted $(P=0.66)$ by the 1996 NRC. However, ADG between actual and predicted results had a tendency $(P$ $=0.08)$ to be different for 3-yr-old cows and was different $(P=0.03)$ for 6 -yr-old cows. In this environment and nutritional management, 1996NRC accurately predicted ADG when cows were in a positive energy balance due to a static physiological state (growth) without the demands of gestation or lactation. However, the 1996NRC overpredicted ADG when cows were in a dynamic physiological period, such as early lactation, but as lactation progressed and nutrient demands for lactation decreased, the 1996NRC accurately predicted ADG. This difference between early and late lactation may have contributed to an underestimation of nutrient needs for lactation.

New Mexico. Beef cows from the Corona Range and Livestock Research Center (CRLRC) in New Mexico were developed and maintained using a conservative nutritional management scheme (Table 3). The CRLRC is considered a piñon-juniper rangeland with blue grama as the predominate forage. Average elevation for CRLRC is $1,900 \mathrm{~m}$ with an average rainfall of $4.0 \mathrm{~cm}$, most of which occurs in July and August (Torell et al., 2008). Heifers were developed at a slow rate of gain $(0.29 \mathrm{~kg} / \mathrm{d})$ on native dormant range with very little additional supplementation. In most years, cows received $100 \mathrm{~kg} \cdot \mathrm{cow}^{-1} \cdot \mathrm{yr}^{-1}$ or less of
Table 3. Actual and NRC-predicted ADG for heifers and 2- and 3-yr-old cows from the Corona Range and Livestock Research Center in Corona, $\mathrm{NM}^{1}$

\begin{tabular}{|c|c|c|c|c|}
\hline Item & Actual & $1996 \mathrm{NRC}^{2}$ & SEM & $P$-value \\
\hline \multicolumn{5}{|c|}{ Weaning to precalving ADG, $\mathrm{kg} / \mathrm{d}$} \\
\hline Heifers & -0.03 & 0.00 & 0.04 & 0.59 \\
\hline 2- and 3-yr-old cows & - & - & - & - \\
\hline \multicolumn{5}{|c|}{ Precalving to prebreeding ADG, $\mathrm{kg} / \mathrm{d}$} \\
\hline Heifers & 0.28 & 0.14 & 0.02 & 0.02 \\
\hline 2- and 3-yr-old cows & -0.78 & -1.37 & 0.03 & 0.01 \\
\hline \multicolumn{5}{|c|}{ Pre-breeding to weaning ADG, $\mathrm{kg} / \mathrm{d}$} \\
\hline Heifers & 0.68 & 0.88 & 0.05 & 0.07 \\
\hline 2- and 3-yr-old cows & 0.51 & 0.60 & 0.06 & 0.33 \\
\hline
\end{tabular}

supplement with the remainder of their diet consisting of native range (Mulliniks et al., 2011, 2013). Cows could be characterized as low milking $(<7 \mathrm{~kg} / \mathrm{d})$, thin BCS (4.5), and moderate mature size $(\sim 556 \mathrm{~kg})$ and weaned moderate-sized calves $(\sim 253 \mathrm{~kg} / \mathrm{cow})$. Actual and 1996NRCpredicted ADG from weaning (September) to March did not differ $(P=0.59$; Table 3 ) when heifers grazed dormant low-quality native range and were supplemented 0.9 $\mathrm{kg} \cdot$ heifer $^{-1} \cdot \mathrm{d}^{-1}$ of a $36 \% \mathrm{CP}$ supplement (Mulliniks et al., 2013). However, as forage quality increased and heifers exhibited compensatory gain, the 1996NRC underpredicted $(P=0.02)$ ADG from March to May (breeding) and had a tendency $(P=0.07)$ to overpredict ADG from breeding (May) to September. Therefore, with growing heifers, the 1996NRC was accurate when heifer gain was static or at a slight BW loss. However, when the environment (i.e., forage quality) was dynamic and heifers exhibited compensatory growth, the actual and 1996NRCpredicted responses were not in agreement. Under the same environment (i.e., forage quality) and nutritional management scheme (Mulliniks et al., 2011), 1996NRC models predicted that 2- and 3-yr-old cows would lose $(P=0.01)$ more BW during early lactation until breeding compared with actual BW performance. However, 1996 NRC did predict similar $(P=0.33)$ ADG from breeding to weaning compared with actual performance.

Montana. Researchers at the Fort Keogh Range and Livestock Research Laboratory in Miles City, MT, managed beef cows under a restricted-nutrient environment and provided minimal inputs to determine production and economic efficiencies of cattle corresponding to nutrient restrictions. Heifers were from a stable composite population developed at Ft. Keogh (50\% Red Angus, 25\% Charolais, and 25\% Tarentaise) and were divided into 2 groups for their respective lifetime nutritional management treatments. During December to March of each year, cows were either fed $1.8 \mathrm{~kg} / \mathrm{d}$ of alfalfa hay (i.e., adequate) as winter supplemental feed or $1.0 \mathrm{~kg} / \mathrm{d}$ of alfalfa 
Table 4. Actual and NRC predicted ADG for 3-yr-old cows and 7-yr-old cows from the Fort Keogh Range and Livestock Research Laboratory in Miles City, $\mathrm{MT}^{1}$

\begin{tabular}{|c|c|c|c|c|}
\hline Item & Actual & $1996 \mathrm{NRC}^{2}$ & SEM & $P$-value \\
\hline \multicolumn{5}{|c|}{ Initial winter feed to precalving ADG, $\mathrm{kg} / \mathrm{d}$} \\
\hline 3-yr-old cows & 0.35 & -0.15 & 0.05 & $<0.01$ \\
\hline 7-yr-old cows & 0.25 & -0.05 & 0.04 & $<0.01$ \\
\hline \multicolumn{5}{|c|}{ Precalving to prebreeding ADG, $\mathrm{kg} / \mathrm{d}$} \\
\hline 3-yr-old cows & -0.34 & 0.29 & 0.03 & $<0.01$ \\
\hline 7-yr-old cows & -0.54 & -0.51 & 0.02 & 0.41 \\
\hline
\end{tabular}

${ }^{1}$ Source: A. J. Roberts, unpublished data.

${ }^{2}$ Predictions based on Model 1 outputs published for beef cattle (NRC, 2000).

hay (i.e., marginal) based on average quality and availability of winter forage (Roberts et al., 2009). All cows were managed as a single herd throughout the rest of the year until the following winter when they were again separated into their respective winter feeding treatment groups. Actual cow performance and 1996NRC predictions did not interact $(P \geq 0.31$; data not shown) with level of winter supplemental feed for either cow age or feeding period. When comparing pooled supplemental feed group data for winter treatments (November and December) with precalving (March), the 1996NRC model predicted $(P<0.01$; Table 4) 3- and 7-yr-old cows would lose 0.15 and $0.05 \mathrm{~kg} / \mathrm{d}$, respectively, whereas actual ADG was 0.35 and $0.25 \mathrm{~kg} / \mathrm{d}$ for the same cows. However, from precalving to prebreeding, the $1996 \mathrm{NRC}$ overpredicted $(P<$ $0.01)$ ADG for 3-yr-old cows but accurately $(P=0.41)$ predicted ADG for 7-yr-old cows.

Oregon. Data were summarized on 689 cow-calf pairs managed by the Eastern Oregon Agricultural Research Center from June (branding) to weaning (October) on USDA Starkey Experimental Forest and Range during 2000 through 2007. Because of size and topography of the grazing allotment $(\sim 10,125 \mathrm{ha})$, typically, mature cows ( $\geq 4$ yr of age) were used. Grazing allotment consisted of mixed-conifer forested rangelands providing high-quality forage ( $18 \% \mathrm{CP}$ and $<50 \% \mathrm{NDF}$ ) early in the summer grazing period but declined $(\sim 7.0 \% \mathrm{CP}$ and $\sim 56 \% \mathrm{NDF}$ ) in value due to lack of moisture and advancement of plant phenology (DelCurto et al., 2013). Under this environment and management scheme, the 1996NRC overpredicted ( $P<0.01$; Table 5$)$ BW loss by $0.40 \mathrm{~kg} / \mathrm{d}$. When the data were separated by cow age, the 1996NRC consistently and to a similar degree overpredicted BW loss of cows $<10 \mathrm{yr}$ of age and $>10 \mathrm{yr}$ of age $(P=0.99)$.

\section{PERCEIVED GAPS IN THE 1996NRC ENERGETICS MODEL REGARDING GRAZING BEEF COWS}

In general, the 1996NRC was more accurate at predicting cow performance in environments like those found in
Table 5. Actual and predicted ADG for mature ( $\geq 4 \mathrm{yr}$ old) cows grazing NE Oregon mixed-conifer forested rangeland from mid-June to mid-October (weaning) of 2000 to $2007^{1}$

\begin{tabular}{|c|c|c|c|c|}
\hline Item & Actual & $1996 \mathrm{NRC}^{2}$ & SEM & $P$-value \\
\hline All cows, $\mathrm{kg} / \mathrm{d}$ & -0.02 & -0.42 & 0.01 & $<0.01$ \\
\hline Cows $\leq 10 \mathrm{yr}$ old, $\mathrm{kg} / \mathrm{d}$ & 0.00 & -0.41 & 0.01 & $<0.01$ \\
\hline Cows $>10 \mathrm{yr}$ old, $\mathrm{kg} / \mathrm{d}$ & -0.04 & -0.44 & 0.01 & $<0.01$ \\
\hline
\end{tabular}

Virginia and Tennessee vs. locations in the western United States. This relative agreement may be attributed to management in these areas that tends to manage cows for higher body conditions with availability of higher-quality forages or harvested feedstuffs yearlong. In contrast, there are few instances in the semiarid rangeland environment where the model outcomes are similar to actual animal responses to diets. Beef cows grazing in the western United States face challenging and dynamic changes in forage quality, which are usually extreme (i.e., as few as $90 \mathrm{~d}$ of green grass available each year). Because of these seasonal nutrient deficiencies, successful cows became highly adapted to their environment and therefore have become efficient under these management scenarios. Overall, the 1996NRC predicted, with good accuracy, cow performance when physiological, dietary, and environmental factors were less variable or more static, which ultimately creates situations where cattle have reduced coping abilities with environmental stress. In contrast, during periods of dynamic forage quality changes and when cows are in a negative energy balance from a combination of factors including metabolic load of lactation, the $1996 \mathrm{NRC}$ predictions had poorer agreement with actual performance.

We can make the generalization that model prediction accuracy, in response to predicted energy intake, is poorer when the subject of the model is a range cow contending with natural conditions in landscapes typical of semiarid rangelands. Apparently, the model is lacking inputs simulating true energy balance of a range cow. The poorest fits occur when cows are in negative energy balance, pregnant, or lactating in conjunction with grazing large area pastures (600 ha or more).

A common occurrence across these conditions is reactions by the animal initiating adaptive responses to cope with condition extremes such as stress (Stott, 1981). We suggest from the findings of the simulations previously discussed that cows experiencing a dynamic environment are coping with the change by altering nutrient requirements compared with those that are in relatively static surroundings. Cows managed in the more controlled situations or static environments may better fit the model, as shown by the Virginia and Tennessee data sets. 
Generally, stress is regarded as a condition that is adverse to the well-being of the animal (Stott, 1981). Stressful circumstances could include prolonged or extreme climatic change, feed or water scarcity, and relatively higher caloric expenditure for activities such as travel. In response to these conditions, the cow will undertake various reactions to restore physiological integrity. When disruptive external stimuli threaten physiological steady state, homeostasis regulates animal processes (Folk, 1974). So in these extensive environments defined by a semiarid grassland environment, the cow's basal state is constantly challenged by change to which it reacts and attempts to stabilize for survival (Lee, 1965). In this context, the adjustment made by the animal is usually regarded as negative to either productivity or well-being. This relationship is derived from the concept that calories will be diverted from productivity to processes engaged to accommodate coping with the stressor. However, readjustments or adaptations may be favorable when forces or stimuli, being either internal or external, induce changes or adaptations that will benefit a cow to better fits its environment. When this circumstance occurs, cow energetic efficiency could be improved and would create the scenario where a cow may be more productive than the 1996NRC model would predict, as in our case studies. Examples of this phenomenon can be found in the dairy cow or goat experimentally showing BW loss in early lactation and energetically efficient replenishment of body reserves at the end of lactation (Chilliard, 1992; Kharrat and Bocquier, 2010). Another illustration in beef cows was reported after a period of energy restriction, followed by nutrient realimentation during pregnancy, resulted in a rebound in BW with improved efficiency (Freetly et al., 2008). These responses are known by practitioners and in fact are projected to occur and are incorporated into management plans. Such management applications would include spring calving management schemes where pregnant cows experience undernutrition when grazing winter range but regain body condition rapidly while grazing spring and summer forages. The magnitude of this rebound is not accounted for by the 1996NRC model and would have resulted in overfeeding of cows if a producer followed the 1996NRC model predictions. It is also known that the digestive and metabolic changes in the rebound period are functioning within a few days of a situational transformation (Hoch and Agabriel, 2004). Several functional responses to underfeeding and, later, to an altered production environment have been described and classified according to the shape of the response curves (Blanc et al., 2006; Friggens and Badsberg, 2007).

The energy expenditure of a given animal depends on the feeding level (intake) and, as a consequence, nutritional status. Overall, when the balance of energy is
Table 6. The effects of supplements of fish meal on the efficiency of utilization of straw-based diets by sheep ${ }^{1}$

\begin{tabular}{lcc}
\hline \hline Item & No supplement & $120 \mathrm{~g} / \mathrm{d}$ fish meal \\
\hline Initial BW, kg & 45 & 43 \\
Final BW, kg & 45 & 49 \\
ADG, g/d & 0 & 68 \\
Intake, g/d & & \\
$\quad$ Straw & 860 & 760 \\
$\quad$ Molasses & 43 & 43 \\
$\quad$ Fish meal & 0 & 120 \\
Changes in carcass composition & & \\
$\quad$ Protein, g & -140 & +890 \\
$\quad$ Energy, MJ & -59 & -16 \\
$\quad$ Fat, g & $-1,400$ & -930 \\
\hline
\end{tabular}

${ }^{1}$ Adapted from Fattet et al. (1984).

negative, intake is presumed to be an overwhelming driver influencing rate of $\mathrm{BW}$ loss and differential rate of tissue catabolism. However, other nutritional manipulations besides intake can modify BW loss to alter proportions of tissue mobilized such as fat tissue over protein tissue utilization (Leng et al., 1978; Soenen et al., 2013). Fattet et al. (1984) demonstrated how strategic use of RUP supplements during weight loss could potentially have a positive influence on body protein tissue stores. This phenomenon could be an important addition to the model (Table 6). An energetic interaction occurs during periods of tissue mobilization when RUP supplements are fed with adequate dietary supply of glucose for efficient oxidative metabolism, especially when low-quality diets are consumed. In the situation when glucose is limiting (especially high-acetate fermentations), RUP can be converted to glucose, thereby driving lactose synthesis, increasing milk production, and increasing the rate of BW loss (Istasse et al., 1987; Hunter and Magner, 1988; Ørskov et al., 1999). For efficient oxidative metabolism to occur, cellular oxaloacetate is required for conversion of acetyl-CoA derived from acetate (originating from either ruminal fermentation or long-chain fatty acid catabolism) to be converted to ATP in the tricarboxylic acid cycle. Oxaloacetate is derived from glucose directly or indirectly via glucogenic precursors, such as ruminally produced propionate, glycerol, glucogenic amino acids, and ionophores. The need for glucose is elevated when reduced-quality, higher-fiber diets, such as winter range forage, are consumed, thereby promoting a greater ruminal acetate-to-propionate ratio. Consequences to a cow consuming low-quality and low-glucogenic-potential diets would include potential buildup of acetate, leading to conversion of ketones and resulting in an inefficient rate of oxidative metabolism and potential stimulation of futile cycling to remedy the imbalances and adipose tissue mobilization. The lack of adequate glucose has also been shown to negatively impact insulin sensitivity, creating 
Table 7. Bypass protein (fish meal) and glucogenic energy (glucose infusion) effects on feed intake, growth, and feed conversion in lambs fed a diet of oaten chaff ${ }^{1}$

\begin{tabular}{|c|c|c|c|c|}
\hline \multirow[b]{2}{*}{ Item } & \multicolumn{4}{|c|}{ Treatment } \\
\hline & $\begin{array}{c}0 \% \text { DMI } \\
\text { fish meal, } \\
0 \mathrm{~g} / \mathrm{d} \text { glucose } \\
\text { infusion }\end{array}$ & $\begin{array}{c}\text { 6\% DMI } \\
\text { fish meal, } \\
0 \mathrm{~g} / \mathrm{d} \text { glucose } \\
\text { infusion }\end{array}$ & $\begin{array}{c}0 \% \text { DMI } \\
\text { fish meal, } \\
80 \mathrm{~g} / \mathrm{d} \text { glucose } 80 \\
\text { infusion }\end{array}$ & $\begin{array}{l}6 \% \text { DMI } \\
\text { fish meal, } \\
0 \mathrm{~g} / \mathrm{d} \text { glucose } \\
\text { infusion }\end{array}$ \\
\hline Feed Intake, g/d & 890 & 1140 & 770 & 1,070 \\
\hline BW gain, g/d & 100 & 200 & 130 & 260 \\
\hline Feed:gain, g/g & 8.9 & 5.7 & 5.9 & 4.1 \\
\hline
\end{tabular}

${ }^{1}$ Adapted from Leng et al. (1978).

a metabolic situation favoring adipose mobilization and reducing clearance of insulin-dependent intermediates, which ultimately inhibits acetate clearance (Waterman et al., 2006; De Koster and Opsomer, 2013). These dietary scenarios affecting VFA ratios derived from ruminal fermentation are predictable, and requirements for glucogenic precursors could be developed for diet formulations. Leng et al. (1978) reported on the magnitude of diet utilization efficiency when an increased supply of glucose was made available via duodenal infusion in sheep fed oaten chaff. The treatment design used a factorial approach with fish meal as a protein source. The combination of fish meal and glucose infusion improved feed efficiency by nearly 50\% (Table 7). Therefore, a glucose requirement that is expressed with low-quality diets could potentially improve energetic efficiencies. In addition, dairy cattle glucose needs have been identified in relation to physiological stage and could be adapted and fitted to the needs of beef cattle and stage of production (Ipharraguerre and Clark, 2003; Chagas et al., 2007; Adewuyi et al., 2005).

\section{SUMMARY AND CONCLUSIONS}

There are 5 recommendations that could improve the usefulness of the 1996NRC energy models for cows grazing semiarid, extensive environments. First, incorporate adaptive mechanisms into the energy model that reduce estimated energy requirements. Second, because ACTIVITY serves as a means to cope with extremes in weather, terrain, nutrient accessibility, and distance, these factors should be further explored and incorporated into the new model. It is our assumption that adaptive mechanisms reduce the energetic costs associated with various activities, and the 1996NRC model does not account for these activities and subsequent adaptations, resulting in overestimation of caloric needs. Third, energetic value of tissue gain and loss should reflect composition of said gain or loss. Calories and limiting metabolic intermediates derived from tissue should feed back into the model to improve BW and BCS loss predictions. Development of requirements to modify BW loss with protein and caloric intake would be beneficial. Requirements for weight loss are as important as requirements for gain, especially in the brood cow. Fourth, various factors are known to modify animal responses to nutrient intake, such as previous nutritional histories, current and past dietary nutrient intake, previous BW gain or loss, static or dynamic production settings, and herd acclimation (natural adaption) and genetic fitness within the environmental and managerial setting. Lastly, the impact of differing actateto-propionate ratios on energetic efficiency when consuming low-quality diets to meet metabolic intermediate deficiencies for normal oxidative metabolism and protein utilization need to be considered. This could involve minimum quantities of propionate or glucogenic precursors in relation to acetate derived from ruminal fermentation or fatty acids produced from adipose tissue mobilization. Although many unknowns are evident within each of these recommendations, we believe incorporation of these factors and continued adaptation of the 1996NRC energy models with these factors will improve predicted energy costs associated with grazing beef cows, especially in extensive environments.

\section{LITERATURE CITED}

Adewuyi, A. A., E. Gruys, and F. J. C. M. van Eerdenburg. 2005. Non esterified fatty acids (NEFA) in dairy cattle. A review. Vet. Q. 27:117-126.

Albright, J. L. 1993. Feeding behavior of dairy cattle. J. Dairy Sci. 76:485-498.

Bjugstad, A. J., H. S. Crawford, and D. L. Neal. 1970. Determining forage consumption by direct observation of domestic grazing animals. In: range and wildlife habitat evaluation-A research symposium. Misc. Publ. No. 1147. USDA For. Serv. Washington, D.C.

Blanc, F., F. Bocquier, J. Agabriel, P. D'Hour, and Y. Chilliard. 2006. Adaptive abilities of the females and sustainability of ruminant livestock systems. A review. Anim. Res. 55:489-510.

Block, H. C., J. L. Bourne, H. A. Lardner, and J. J. McKinnon. 2010. Evaluation of NRC (2000) model energy requirement and DMI equation accuracy and precision for wintering beef cows in western Canada. Can. J. Anim. Sci. 90:245-258.

Chagas, L. M., J. J. Bass, D. Blache, C. R. Burke, J. K. Kay, D. R. Lindsay, M. C. Lucy, G. B. Martin, S. Meier, F. M. Rhodes, J. R. Roche, W. W. Thatcher, and R. Webb. 2007. Invited review: New perspectives on the roles of nutrition and metabolic priorities in the subfertility of high-producing dairy cows. J. Dairy Sci. 90:4022-4032.

Chilliard, Y. 1992. Physiological constraints to milk production: Factors which determine nutrient partitioning, lactation persistency and mobilization of body reserves. World Rev. Anim. Prod. 27:19-26.

Damiran, D., T. DelCurto, S. Findholt, B. Johnson, and M. Vavra. 2013. Comparison of bite-count and rumen evacuation techniques to estimate diet quantity and quality in grazing cattle. Rangeland Ecol. Manage. 66:106-109.

Darambazar, E., T. DelCurto, D. Damiran, A. A. Clark, and R. V. Taylor. 2007. Species composition and diversity on northwestern bunchgrass prairie rangelands. Proc. West. Sect. Am. Soc. Anim. Sci. 58:233-236.

Davis, J. D., M. J. Darr, H. Xin, J. D. Harmon, and J. R. Russell. 2011. Development of a GPS herd activity and well-being kit (GPS HAWK) to monitor cattle behavior and the effect of sample interval on travel distance. Appl. Eng. Agric. 27:143-150. 
De Koster, J. D., and G. Opsomer. 2013. Insulin resistance in dairy cows. Vet. Clin. North Am. Food Anim. 29:299-322.

DelCurto, T., B. W. Hess, J. E. Huston, and K. C. Olson. 2000. Optimum supplementation strategies for beef cattle consuming low-quality roughages in the western United States. J. Anim. Sci. 77:1-16.

DelCurto, T., S. A. Wyffels, C. J. Mueller, D. Damiran, E. Darambazar, M. Vavra, and R. A. Riggs. 2013. The influence of habitat type on vegetation quality in mixed-conifer forested rangelands. Proc. West. Sect. Am. Soc. Anim. Sci. 64:336-339.

DelCurto, T., M. Porath, C. T. Parsons, and J. A. Morrison. 2005. Management strategies for sustainable beef cattle grazing on forested rangelands in the Pacific Northwest. Rangeland Ecol. Manage. 58:119-127.

Fattet, I., F. D. Hovellp, E. R. Ørskov, D. J. Kyle, K. Pennie, and R. I. Smart. 1984. Undernutrition in sheep: The effect of supplementation with protein on protein accretion. Br. J. Nutr. 52:561-574.

Folk, G. E. 1974. Textbook of environmental physiology. 2nd ed. Lea and Febiger, Philadelphia, PA.

Freetly, H. C., J. A. Nienaber, and T. Brown-Brandl. 2008. Partitioning of energy in pregnant beef cows during nutritionally induced body weight fluctuation. J. Anim. Sci. 86:370-377.

Friggens, N. C., and J. H. Badsberg. 2007. The effect of breed and parity on curves of body condition during lactation estimated using a non-linear function. Animal 1:565-574.

Hoch, T., and J. Agabriel. 2004. A mechanistic dynamic model to estimate beef cattle growth and body composition: 1 . Model description. Agric. Syst. 81(1):1-15.

Hollingsworth-Jenkins, K. J., T. J. Klopfenstein, D. C. Adams, and J. B. Lamb. 1996. Ruminally degradable protein requirements of gestating beef cows grazing native winter sandhills range. J. Anim. Sci. 74:1343-1348.

Horsley, D. S. 2002. Determining the nutritional status of mature beef cows. MS Thesis. Virginia Polytechnic Institute and State University, Blacksburg.

Hunter, R. A., and T. Magner. 1988. The effect of supplements of formaldehyde-treated casein on the partitioning of nutrients between cow and calf in lactating Bos indicus $\times$ Bos taurus heifers fed a roughage diet. Aust. J. Agric. Res. 39:1151-1162.

Ipharraguerre, I. R., and J. H. Clark. 2003. Usefulness of ionophores for lactating dairy cows: A review. Anim. Feed Sci. Technol. 106:39-57.

Istasse, L., N. A. Macleod, E. D. Goodall, and E. R. Ørskov. 1987. Effects on plasma insulin of intermittent infusions of propionic acid, glucose or casein into the alimentary tract of non-lactating cows maintained on a liquid diet. Br. J. Nutr. 58:139-148.

Kharrat, M., and F. Bocquier. 2010. Adaptive responses at the whole lactation scale of Baladi dairy goats according to feed supply and level of body reserves in agro-pastoral feeding system. Small Rumin. Res. 90:120-126.

Klosterman, E. W., L. G. Sanford, and C. F. Parker. 1968. Effects of cow size and condition and ration protein content upon maintenance requirements of mature beef cows. J. Anim. Sci. 27:242-246.

Lardy, G. P., D. C. Adams, T. J. Klopfenstein, and H. H. Patterson. 2004. Building beef cow nutritional programs with the 1996 NRC beef cattle requirements model. J. Anim. Sci. 82:E83-E92.

Lee, D. H. R. 1965. Climatic stress indices for domestic animals. Int. J. Biometeorol. 9:29-35.

Leng, R. A., S. Economides, and F. M. Ball. 1978. The effect on growth of supplying glucose continuously into the duodenum of lambs on low protein diets. Proc. Aust. Soc. Anim. Prod. 12:134.
Mulliniks, J. T., S. H. Cox, M. E. Kemp, R. L. Endecott, R. C. Waterman, D. M. VanLeeuwen, L. A. Torell, and M. K. Petersen. 2011. Protein and glucogenic precursor supplementation: A nutritional strategy to increase reproductive and economic output. J. Anim. Sci. 89:3334-3343.

Mulliniks, J. T., D. E. Hawkins, K. K. Kane, S. H. Cox, L. A. Torell, E. J. Scholljegerdes, and M. K. Petersen. 2013. Metabolizable protein supply while grazing dormant winter forage during heifer development alters pregnancy rate and subsequent in-herd retention rate. J. Anim. Sci. 91:1409-1416.

Ørskov, E. R., D. E. Meehan, N. A. MacLeod, and D. J. Kyle. 1999. Effect of glucose supply on fasting nitrogen excretion and effect of level and type of volatile fatty acid infusion on response to protein infusion in cattle. British J. Nutr. 81:389-393.

National Climatic Data Center. 2013. Weather data generated from NOAA is being cited. www.ncdc.noaa.gov. (Accessed 29 August 2013.)

NRC. 1984. Nutrient requirements of beef cattle. 6th rev. ed. Natl. Acad. Press, Washington, DC.

NRC. 2000. Nutrient requirements of beef cattle. 7th rev. ed. Update 2000. Natl. Acad. Press, Washington, DC.

Patterson, H. H., D. C. Adams, T. L. Klopfenstein, and G. P. Lardy. 2006. Application of the 1996 NRC to protein and energy nutrition of range cattle. Prof. Anim. Sci. 22:307-317.

Ray, D. E., and C. B. Roubicek. 1971. Behavior of feedlot cattle during two seasons. J. Anim. Sci. 33:72-76.

Rittenhouse, L. R., C. L. Streeter, and D. C. Clanton. 1971. Estimating digestible energy from digestible dry and organic matter in diets of grazing cattle. J. Range Manage. 24:73-75.

Roberts, A. J., E. E. Grings, M. D. MacNeil, R. C. Waterman, L. Alexander, and T. W. Geary. 2009. Implications of going against the dogma of feed them to breed them. Proc. West. Sect. Am. Soc. Anim. Sci. 60:85-88.

Russell, M. L., D. W. Bailey, M. G. Thomas, and B. K. Whitmore. 2012. Grazing distribution and diet quality of Angus, Brangus, and Brahman cows in the Chihuahuan desert. Rangeland Ecol. Manage. 65:371-381.

Soenen, S., E. A. P. Martens, A. Hochstenbach-Waelen, S. G. T. Lemmens, and M. S. Westerterp-Plantenga. 2013. Normal protein intake is required for body weight loss and weight maintenance, and elevated protein intake for additional preservation of resting energy expenditure and fat free mass. J. Nutr. 143:591-596.

Stott, G. H. 1981. What is animal stress and how is it measured? J. Anim. Sci. 52:150-153.

Torell, L. A., K. C. McDaniel, S. Cox, and S. Majumdar. 2008. Eighteen years (1990-2007) of climatological data on NMSU's Corona Range and Livestock Research Center. Res. Rep. No. 761. New Mexico Agric. Exp. Stn., Las Cruces. p. 1-20.

Waterman, R. C., J. E. Sawyer, C. P. Mathis, D. E. Hawkins, G. B. Donart, and M. K. Petersen. 2006. Effects of supplements that contain increasing amounts of metabolizable protein with or without Ca-propionate salt on postpartum interval and nutrient partitioning in young beef cows. J. Anim. Sci. 84:433-446.

Wyffels, S. A., T. DelCurto, and A. A. Clark. 2013. Influence of beef cattle stocking density on utilization of vegetative communities in a late-spring early-summer native bunchgrass prairie. Proc. West. Sect. Am. Soc. Anim. Sci. 64:332-335. 